\title{
Lived Experiences of Adolescents with Internet Addiction
}

\author{
Suryani Suryani ${ }^{1}$, Aat $\operatorname{Sriati}^{1}$, Nurul Septiani ${ }^{1}$ \\ ${ }^{1}$ Faculty of Nursing, Universitas Padjadjaran, Indonesia \\ Corresponding Author: Suryani Suryani (suryani@unpad.ac.id)
}

Received: 24 June 2020

Revised: 7 August 2020

Accepted: 11 August 2020

\begin{abstract}
Background: Internet addiction has been and will become a serious global problem in the future. Understanding the lived experiences of adolescents with Internet addiction is crucial for providing appropriate nursing interventions.

Purpose: This study aimed to explore the lived experiences of adolescents with Internet addiction.

Methods: This was a phenomenological study involving in-depth interviews with seven adolescents with Internet addiction. Data were analyzed using the Colaizzi's approach of analysis.

Results: Six themes were identified from this study: the feeling that playing with the Internet is more important than the school; become "too lazy to move" and unable to manage time; physical health disorders due to Internet addiction; the feeling that it is difficult to be away from the Internet, and social interaction difficulties in the real world, which then leads to hostile attitude due to the lack of ability to control emotions.

Conclusion: The lived experience of adolescents with Internet addiction is complicated and impacted on all aspects of teenagers' lives. These findings provide insights for nurses in preventing and overcoming Internet addiction problems among teenagers.
\end{abstract}

Keywords: Adolescents; lived experience; Internet addiction

How to Cite: Suryani, S., Sriati, A., \& Septiani, N. (2020). Lived experiences of adolescents with Internet addiction. Nurse Media Journal of Nursing, 10(2), 158-171. doi:10.14710/nmjn.v10i2.31161

Permalink/DOI: https://doi.org/10.14710/nmjn.v10i2.31161

\section{BACKGROUND}

Currently, Internet use has become one of the issues that attract the attention of the academic world since Internet use may trigger Internet addiction (Young \& De Abreu, 2011). According to Young (2017), a person is said to have Internet addiction when he or she uses the Internet for more than 6 hours per day in three consecutive months. Meanwhile, according to Yang and Tung (2014), Internet addiction in adolescents is characterized by the difficulty in controlling the desire to continue using the Internet respectively. Databoks (2020), in their survey of Internet use in Indonesia among Indonesians aged 16-60 years stated that Indonesians spend nearly 8 hours per day on the Internet. This means that Internet users in Indonesia have the potential to suffer from Internet addiction if the Internet is used not for productive reasons. 
According to a survey conducted by the Association of Indonesian Internet Service Providers (Asosiasi Penyelenggara Jasa Internet Indonesia, APJII) in 2017, the total number of Internet users in Indonesia continues to grow year to year. The total number of Internet users in this country was 132.7 million people in 2016, which increased to 143.26 million in 2017 and 175.3 million in 2020 , or $64 \%$ of the total population of Indonesia (Databoks, 2020). Most of the Internet users live in Java Island.

A preliminary study conducted by the researchers at the Public Health Centers (Pusat Kesehatan Masyarakat, Puskesmas) in Cimahi, Indonesia found some teenagers used the Internet more than 8 hours and found it difficult to free from Internet. For example, $\mathrm{R}$ who 15 years old and the son of one of the health cadres in the area. He was a student of one of the Vocational High School in Bandung. It was very difficult for R to control himself in terms of using the Internet or playing online games in Internet cafes. R usually played online games on the Internet after school until midnight, around 12 to 1 a.m. If, for example, R fell asleep earlier, such as at 7 p.m., he would wake up at 11 p.m. or 12 a.m. and played the game with his friends until dusk. R often overslept, missed the fajr prayer, and late to school. He did not only play the online game at home but also went to the Internet cafe from noon to before sunset. Sometimes, his mother had to pick him up from the Internet cafe to stop him from playing the game. R said that he often got sick due to fatigue and lack of sleep so he often skipped school. When R's mother forbade him from playing with his mobile phone, $R$ could study or sleep well at night; R got angry with his mother instead.

Internet addiction in adolescents can have negative impacts such as triggering obsessivecompulsive behaviors, depression, anxiety, and hostile attitude towards the real world. Addiction can also make adolescents experience fatigue, disturbed sleep patterns, decreased academic achievement, and also posing the risk for juvenile delinquency (Kim, 2013; Li, O'Brien, Snyder \& Howard, 2015). This notion is supported by the works of Wee et al., (2014), Ybarra, Alexander, and Mitchell (2005), and Yen, Chou, Liu, Yang, and $\mathrm{Hu}$ (2014) which also suggested that Internet addiction also have a significant impact on adolescent life, such as triggering depression, anxiety, physical and mental health deterioration, disrupted interpersonal relationships and decreased performance on life daily. Hakim and Raj (2017) also added that the negative impact of Internet addiction in adolescents includes the tendency to access the Internet even though friends are trying to talk to them. The habit of accessing the Internet also affects the eyes, causes difficulty to sleep, often leads to procrastinating, and decreases academic achievement due to the strong preference to access the Internet than to study.

With so many studies suggested negative impacts of Internet use in adolescents, no studies explored in-depth the experience of adolescents with Internet addiction. it is necessary to understand the life experiences of adolescents regarding the use of the Internet, especially the experiences of those who experience Internet addiction.

\section{PURPOSE}

This study aimed to gain a deep understanding of the lived experiences of adolescents with Internet addiction. 


\section{METHODS}

\section{Research design and participants}

This study used a phenomenological approach to answer questions about experiences or meanings from the participants' viewpoints (Tauba, Suryani, \& Rafiyah, 2020). This approach is considered appropriate as it allowed the researchers to gain a deep understanding of the participants' experiences. Seven participants who were selected using a purposive sampling technique were involved in this study. The inclusion criteria for participants were adolescents who use the Internet for more than six hours per day in 3 consecutive months for non-productive leisure activities and aged between 12 to 18 years old. Meanwhile, the exclusion criterion was adolescents who withdrew from participation in the study. Informants were recruited through the Puskesmas based on the information from health cadres working in the area of study.

\section{Data collection}

Data collection was performed through in-depth interviews by asking open-ended questions using the probing question techniques to explore the lived experiences of adolescents with Internet addiction. Three interviews, each lasted 45-minute to 1-hour, were performed on each informant. The first interview aimed to collect information while the second was to validate the transcript, and the third was to validate the themes.

\section{Data analysis}

Data collected were then analyzed using the Colaizzi's approach. Information submitted by the participants were then transcribed. The transcribed interviews were read and reread several times to get insight. Each transcript was analyzed for a significant statement. There were 165 significant statements obtained from the transcript. All significant statements were transformed to formulated meaning. The next step was to look for common categories or sub-themes across the entries for each significant statement and formulated meaning. There were $17 \mathrm{sub}$-themes derived from significant statements and formulated meaning. The 17 sub-themes were then analyzed and categorized into 6 themes by reading and re-reading the transcribed interviews, significant statements, formulated meaning, and sub-themes. Narratives were developed using the themes based on the statements from the participants. To maintain strictness in data analysis, bracketing was employed in the analysis process to understand the experiences of the participants as they truly were. The researchers reviewed each of the participants' significant statements and assigned meaning to each. This required the consideration of both the explicit and implicit meanings inherent in each statement.

\section{Ethical considerations}

Before starting the data collection, ethical clearance was obtained from the Ethics Research Committee of the Faculty of Medicine, Universitas Padjadjaran with the issuance of ethical clearance number 771/UN6.KEP/EC/2019. Before collecting data, informed consent was obtained from the parents of the participants.

\section{RESULTS \\ Informant characteristics}

Seven adolescents participated in this study, consisting of three girls and four boys. The age of the informants ranged from 13-18 years old and they were studying in Junior High 
School and Senior High School. The informants accessed the Internet using mobile phones and computers and had started to access the Internet since they were in elementary school. They mostly used the Internet to play online games, watch Korean dramas, and access social media.

\section{Themes}

There were six themes identified in this study: the feeling that playing with the Internet is more important than the school; become "too lazy to move" and unable to manage time; physical health disorders due to Internet addiction; the feeling that it is difficult to be away from the Internet; and social interaction difficulties in the real world, which then leads to hostile attitude due to the lack of ability to control emotions. These themes were retrieved from the statements from the informants during the interview.

\section{Feeling that playing with the Internet is more important than the school}

Based on the results of the analysis after repeated readings of transcripts, the first theme that emerged was "feeling that playing with the Internet is more important than school". All informants experienced this feeling, although in different ways. Informant 2 felt that the game scores were more important than the school grades:

"It's important to play the game; for school, we just need to pass the exams. Grades are not important. If I get poor grades, just (take remedial tests) to fix it." (P2.49)

Informant 1 added that since he/she became familiar with online games and social media, he/she did not even bother to study for final exams. This informant was more focus on social media and games:

"Honestly, my academic performance is deteriorating... since I become familiar with social media and games, even when I have a test, I never study. I just want to play games. When my parents told me to study, I get angry." (P1.10)

A similar statement was also given by Informant 3 who also never bothered to study and was more focus on playing games than studying:

"I never study. What is the use of studying? It's better to play games." (P3.32)

Informant 3 also stated that the most important thing for him/her was to play games, he/she did not care about the grades:

"If my school grades decline, I don't care. The important thing is just able to continue to the next grade. The exam grades do not matter." (P3.45)

\section{Become "too lazy to move" and unable to manage time}

"Too lazy to move" or Mager is the term that Indonesian adolescents often use to describe the laziness to do any other activities. Adolescents use this term when they feel that they are already comfortable with their current activity, especially leisure activities like relaxing, lying down, or playing with the Internet, that they do not have the eagerness to do anything else. This theme has some sub-themes as described below.

Mager or "too lazy to move"

This experience was expressed by several informants. These informants revealed that as a result of prolonged Internet use or playing games, they became too lazy to move: 
"If, for example, hmmm (I) have already sat on the bed in my room and playing with my mobile, then (I) just keep playing with my mobile. I cannot move, cannot get up from the bed. So, mager. If a friend invites me to his or her home, I refuse because I am 'too lazy to move' and (I) am to absorbed with the Internet." (P1.31)

\section{Forget time}

Playing with the Internet is a fun activity that causes the informants to forget time. They spent all their time playing with the Internet. Informant 4 described this situation:

"All my activities were neglected because I spend all my time was to play games and do other activities on the Internet." (P4.34)

Informant 6 also described in detail the reason why he/she forgot the time:

"The negative impact of playing with the Internet if you ask me, I become ignorance towards the time because when (I) go to social media, (I) become increasingly curious (and I) want to know more." (P6.23)

Another informant also said that because he/she was too engrossed in playing Internet, he/she had no time for doing other activities:

“... as a consequence I become too lazy to do other activities." (P6.23)

\section{Physical health disorders due to Internet addiction}

Informants stated that because they were engaged in playing with the Internet for a long duration, they experienced headache, pain in the eyes, pain in the shoulders, and stiffness:

"So, when (I) play with my mobile phone for too long, yes, I feel dizzy, pain in the eyes, and then my body feels stiff, not feeling well because I spend too much time on the bed without moving." (P1.26).

Informant 4 stated that his/her physical condition was deteriorating because he/she spent too much time playing games and also due to lack of rest or sleep:

"(I) have a headache. Because of lack of sleep, because well, I play games continuously. Other than lack of sleep, (I) also feel pain in (my) eyes." (P4.8).

\section{Feeling that it is difficult to be away from the Internet}

Almost all informants felt that they were dependent on the Internet. They felt that they could not stop using the Internet and forgot everything. Furthermore, they also felt that there was something missing in their life if they did not access the Internet. They felt that they were inseparable from the Internet:

"Because (I am) addicted to a mobile phone, I feel that something is missing in my life if I don't have my mobile phone with me." (P1.62).

Informant 1 also shared the feelings of hollowness and like dying when not playing with his/her mobile phone because he/she thought that the mobile phone was a necessity:

"Well, addicted. So, it becomes a very important thing that I need in my life. If I don't have my mobile phone, I feel like I am dying." (P1.67) 
Even participants felt playing games the game it as a remedy for his/her boredom:

"Playing games for me is the remedy for "bete" and boredom. So when I play games, I feel happy and excited." (P1.39)

Bete is a term often used by adolescents in Indonesia to express boredom. According to the Wiktionary, the word bete or BT is an abbreviation of "bored totally" or "boring total" or totally bored. The word bête, in addition to showing boredom, also contains the element of feeling upset about a condition or situation.

Because they cannot be separated from the Internet, the informants did various ways to always be connected to the Internet such as, for example, looking for facilities that are always connected to the Internet. They even stole their parents' money to buy Internet credits. When the Internet credit was used up, one of the informants used his/her parents' or family's hotspot in order not interrupting the Internet connection:

"If my credit is used up, I asked for a hotspot to my mother or sister, or go to a friend's house that has a wifi connection to play." (P5.60)

Informants also said that they would borrow money from their friends when their Internet credit was used up:

"I often call my friend at midnight to buy Internet credit. It happens that my friend owns a mobile phone counter. I pay for it the next day when I go to school." (P6.43)

Another way that the informants used was to secretly take the parents' money to buy credit:

“... and then I went to my mom's room, looking for money in her cupboards. When I saw small changes such as one thousand, two thousand, I took them and collected them. Then I used the money to buy the Internet credit. But I didn't tell my mom that I took the money." (P6.55)

\section{Social interaction difficulties in the real world}

This theme has two sub-themes: informants feel more comfortable in the virtual world than the real world and informants feel that it is difficult to do social interactions in the real world.

Feel more comfortable in the virtual world than the real world

Prolonged use of the Internet has caused the informants to feel more comfortable in the virtual world than in the real world:

"The social interaction is via a game, via online, online game. While talking through a phone call." (P4.11)

Informants stated that they would prefer to play with their mobile phone than hanging out with their friends because they thought that their friends were sometimes boring:

"If I am invited to play (with my friends) hmm yes I would choose to play with my mobile phone because playing with friends is sometimes boring. So, it is more comfortable to play with the mobile phone than to play with them directly." (P7.18 
Difficult to do social interactions in the real world

This subtheme was identified based on the statements from some participants that clearly revealed the feeling that it was difficult and annoying to do social interactions with friends and family:

"When I am playing with my mobile, I cannot do social interactions with friends." (P1.32).

Besides having difficulties in interacting with friends, informants also stated that they rarely interacted with family when playing games:

"When I'm playing a game, my focus is on my mobile phone, so I and my family rarely interact, rarely talk, because I like to play the game continuously. I keep on playing with my mobile phone." (P1.60).

The same condition was also experienced by the informant 2 :

"Well, I feel that I don't really interact with my friends. It should be that I interact with them, talking to them, but I instead play on my mobile phone." (P2.108)

The informant added that he/she never had a long conversation with his/her friends as he/she would revert back to his/her mobile phone:

"If I meet a friend, I will chat a bit as usual. But only briefly, around 15 minutes or 10 minutes. After that, we are back to our own mobile phone, busy with it." (P6.14)

\section{Hostile attitude due to the lack of ability to control emotions}

All informants revealed that they had experienced emotional disturbance since they started to experience Internet addiction. The sub-themes of this theme are hostility between Internet users, angry and annoyed when using the Internet too much, scolded by parents because of playing with the Internet continuously, and felt that it was difficult to interact with the surrounding environment or the real world.

Other than the excitement and the fun in playing games, there was also hostility among friends when they played games. Informant 3 mentioned about this hostility:

"Playing Internet like online games is exciting, but sometimes we mock each other. I also fought in the past...with my friends. Because I was so pissed off, I pushed his/her head into a container full of water." (P3.107)

In addition to fights between Internet users when losing a game, frustration and anger were also expressed when they lost the game:

"Slam the table like this (while demonstrating who he/she slammed the table). Well, I just grumble when I lose a game." (P3.55).

In contrast to informant 3 , informant 4 slammed the mobile phone when he/she was angry and annoyed because he/she lost the game:

"I am angry if I lose the game. I once slammed my mobile phone because I was pissed off." (P4.18) 
The informants were not only angry when they lost the game. They also got angry when they were disturbed while playing the game:

"...when I play games online if a friend calls me (on my mobile), I will reject (the call) because I can't be disturbed." (P4.10)

\section{DISCUSSION}

\section{Feeling that playing with the Internet is more important than the school}

The first theme identified in this study is "feeling that playing with the Internet is more important than the school". Informants revealed that they never study and grades in school have declined since they started to use the Internet for social media, online games, Korean drama, and so on. This results in declined school grades, and according to the informants, it is not something that they should worry about because they think that they just need to pay a certain amount of money to move up to the next grade in school. This is in line with the findings of Young and De Abreu (2011) stating that Internet addicts cannot stop the desire to go online that they lose control of their use of the Internet. Internet addiction is as bad as drug, alcohol, and gambling addictions which result in academic failure and reduced performance. This is also supported by Leung and Lee (2016) who stated that Internet addiction is excessive use of the Internet that it disrupts daily activities.

Internet addiction, especially online game addiction, is an addiction that is often encountered these days due to the increasingly easy access to the Internet. Currently, online games can be accessed and played not only through a personal computer but also through a smartphone (Montag \& Reuter, 2017). Masya and Candra (2016) suggested that online games affect students by making them lazy to learn and often use their free time to play the game. Online games also trigger students to find time to play, even skip school just to play games. A similar phenomenon was also seen in this study, with one of the informants stated that games already disturbed his study: Since he becomes familiar with social media and games, even when he has a test, he never studies.

\section{Become "too lazy to move" and unable to manage time}

The emergence of the Internet as an electronic media was initially aimed at becoming an intermediary tool for interactions between people, such as through social media, entertainment supporting applications, and so on (Young, 2009). One of the features in the Internet world that are quite developed, and even provide entertainment is online gaming (Leung \& Lee, 2016). However, adolescents can be negatively affected by it, as revealed in this study. When the informants become addicted to the Internet, they become "mager" or too lazy to move and just lying on the bed in the bedroom to play with the Internet. The informants even forget to take a bath. In addition, the negative impact of the online games is that the real world activities become neglected because the players are absorbed in the game that they neglect their main activities and find it difficult to manage time (Chiu, Lee \& Huang, 2004). Just as in the study by Chiu, et al (2004), the informants in this study revealed that they do not want to do activities when they are already on their mobile phone. They find it difficult to manage their time because they are too absorbed in playing with the Internet.

Young (2009) mentioned that playing with the Internet is an activity that can drain emotions and make people spend more time with the Internet, losing control of time, 
experiencing academic difficulties, and experiencing difficulties in building and maintaining relationships. Individuals who are addicted to the Internet will also refuse to sleep, eat, exercise, and do social and financial activities that it disrupts health and other life activities.

\section{Physical health disorders due to Internet addiction}

Excessive use of the Internet does not only cause mental disorders, but also causes physical disorders. According to Hasanzadeh, Beydokhti, and Zadeh (2012), physical health disorders due to the excessive use of the Internet include headache, pain, and stiffness of the neck, back (carpal tunnel syndrome), as well as a reduced immune system that addicts easily get sick. This concurs with the experiences of the informants. When they played with the mobile phone for a long time, they would feel dizzy, pain in the eyes, and stiffness in their body.

According Wijaya, Wijayanthi, and Widyastuti (2019), there is a correlation between prolonged sitting with lower back pain among teenagers due to playing online games. Factors that cause back pain include posture abnormality resulting in nerve disorders and impaired blood circulation and the habit of sitting in one position for a long time without any break. Another study by King, et al. (2013) revealed that people who experience Internet addiction may experience intense insomnia. This is also mentioned by the informant in this study:

\section{Feeling that it is difficult to be away from the Internet}

The third theme in this study is "feeling that it is difficult to be away from the Internet". The Internet is a very important necessity for all informants that the informants feel that they are going to die if they do not have access to the Internet. Even to be offline for one hour is already very difficult for the informants. Furthermore, when they tried to turn off their mobile phone to sleep, they feel restless and anxious that they turn on the mobile phone again. This makes the informants stay up late every night.

According to Perdew (2014) doing fun activities on the Internet can make someone addicted because it increases dopamine production. The pleasurable activities performed repeatedly on the Internet will make the brain respond by producing more dopamine so the person want to do it again and again. This situation will spur someone to increase the duration or intensity of Internet use and it will be difficult to break away from it.

Masya and Candra (2016) reported that there are internal and external factors that cause an adolescent to become addicted. The internal factors are boredom at home, inability to set priorities in life, and lack of self-control. The external factors are less controlled environment because they see other friends also play with the Internet, lack of good social relationships, and high parental expectation that is imposed on the child. This is supported by Ariani, Suryani, and Hernawaty (2018) in their research that suggested parental attachment as the most dominant factor for the occurrence of Internet addiction.

When not connected to the Internet, the individual feels like he/she loses one important thing in him/herself, so they experience the urge to do various attempt to be able to reconnect with the Internet. Based on the findings of Weinstein, Dorani, Elhadif, 
Bukovza, Yarmulnik, and Dannon (2015), Internet addicts have similar characteristics to drug addicts, which is that their thought and emotion are bound to what makes them addicted. In more severe cases, the urge of the mind and emotion make a person do anything, including committing crimes as found from this study. This is supported by the finding of Weinstein, et al. (2015) who studied 120 students. They discovered that $50 \%$ of respondents said they feel uneasy if their mobile phone is not connected to the Internet. When they were asked about items to be rescued in the event of a fire, respondents made the mobile phone as their top priority. This is congruent with the results of a study conducted by Mudrikah (2009) in Sidoarjo, Indonesia, on 127 high school students, which found that Internet addiction causes psychological problems for users that trigger them to do various bad behaviors to always be connected to the Internet. This is also proven in this study as the informants stated that they took their parents' money secretly to buy Internet credit or borrow from a friend to be able to buy the credit.

Playing with the Internet, particularly playing online games, may cause uninterrupted pleasure. Several researchers have reported that the computer and online games should receive attention as they can cause dependence for its users (Holt \& Kleiber, 2009; Hsu, Wen, \& Wu, 2009). However, until recently the Indonesia government has not yet had a strategic program to overcome this problem. Although there has been a joint decree with four ministers (SKB 4 Menteri) regarding overcoming Internet addiction in adolescents, the implementation is still not going well.

\section{Social interaction difficulties in the real world}

A person who is addicted to the Internet will focus on the Internet only that he or she will feel more comfortable in the virtual world than in the real world, leading to withdrawal from social interactions. Individuals who are addicted to the Internet will spend more time using the Internet than interacting directly with family and friends. Kusumawardani (2015) in her study found that teenagers with Internet addiction especially game addiction will have trouble in social interaction because too focus on the game.

In line with Kusumawardani (2015), in this study, it was also found the link between Internet addiction and various unhealthy user behaviors, including lack of social skills. Individuals who lack social skills will have more severe Internet addiction and they perceive that friendship in the virtual world is easier to build than friendship in real life (Mustafa, 2011). Also, when gathering with families or friends, an Internet addict will be preoccupied with his/her mobile phone to update their status on Twitter, Facebook, and other social media so that they cannot communicate well. They are only busy with their mobile phone. Therefore, the Internet and social media make people anti-social and do not care about their environment (Hasanzadeh et al, 2012).

\section{Hostile attitude due to the lack of ability to control emotions}

Hostility is one of the negative effects arising from the excessive use of the Internet. It is as expressed by a participant who experienced hostility or fights with other Internet users due to anger and emotional trigger. This negative emotion will lead to violent behavior when they cannot cope with the situation. Gezgin, Cakir, and Yildirim (2018) found that there is a strong relationship between the inability to control emotions and Internet use behavior. This concurs with Choo, Gentile, Sim, Li, Khoo, and Liau, (2010) and Gezgin 
et al. (2018) who stated that the symptoms caused by prolonged use of the Internet are hostility, unfriendly behavior, mocking between Internet users, and hate between users. Furthermore, Nie (2001) found that online social interaction has a greater psychological burden than offline interaction. Someone who interacts online more often mock one another compared to those who interact offline, which will then cause hostility.

In contrast, a study by Hakim and Raj (2017) found that when facing a problem, participants in their study accessed the Internet more frequently to open Youtube for funny videos, Youtubers' vlogs, and social media to just share their feeling with friends. Participants felt relieved and happy after accessing the Internet that their mood improved. On the other hand, an experimental study by Barlett, Harris, and Baldassaro (2017) showed that action online games significantly increase the aggressiveness of the users. This type of hostility is more apparent when a person often plays action games (Ko, Yen, Chen, Yeh, \& Yen, 2009). Therefore, aggressive behavior in an online game is often associated with the hostility between online game players, making them prone to the Internet Gaming Disorder (IGD). The expressions of some informants in this about their anger and resentment when using the Internet to play online games support this notion. Feelings of anger and resentment also have an impact on the surrounding environment.

\section{CONCLUSION}

This study explored the lived experiences of adolescents with Internet addiction. Six themes of the general impacts of Internet addiction on informants' lives were identified, including the feeling that playing with the Internet is more important than the school; become "too lazy to move" and unable to manage time; physical health disorders due to Internet addiction; the feeling that it is difficult to be away from the Internet; and social interaction difficulties in the real world, which then leads to hostile attitude due to the lack of ability to control emotions. The findings of this study provide insight for health professionals, especially nurses in preventing and overcoming Internet addiction problems among adolescents. However, further research is needed on appropriate interventions in overcoming Internet addiction with reference to the findings of this study.

\section{ACKNOWLEDGMENT}

The authors would like to thank all participants, the ALG research group, and the Center for Continuity of Care, Faculty of Nursing, Universitas Padjadjaran.

\section{CONFLICT OF INTEREST}

There is no conflict of interest in this article.

\section{REFERENCES}

Ariani, P., Suryani, S., \& Hernawaty, T. (2018). Relationship between academic stress, family and peer attachment with Internet addiction in adolescents. Jurnal Keperawatan Padjadjaran, 6(3), 215-226. doi:10.24198/jkp.v6i3.483

Asosiasi Penyelenggara Jasa Internet Indonesia (APJII). (2017). Hasil survei penetrasi dan pengunan Internet Indonesia 2017 [Results of the 2017 indonesian Internet user and penetration survey]. Retrieved from https://apjii.or.id/content/read/39/ 342/Hasil-Survei-Penetrasi-dan-Perilaku-Pengguna-Internet-Indonesia-2017 
Barlett, C. P., Harris, R. J., \& Baldassaro, R. (2007). Longer you play, the more hostile you feel: Examination of first person shooter video games and aggression during video game play. Aggressive Behavior, 33(6), 486-497. doi:10.1002/ab.20227

Chiu, S., Lee, J., \& Huang, D. (2004). Video game addiction in children and teenagers in Taiwan. Cyberpsychology \& Behavior, 7(5), 571-581. doi:10.1089/cpb.2004.7.571

Choo, H., Gentile, D. A., Sim, T., Li, D., Khoo, A., \& Liau, A. K. (2010). Pathological video-gaming among Singaporean youth. Annals of the Academy of Medicine, Singapore, 39(11), 822-829.

Databoks (2020). Orang Indonesia habiskan hampir 8 jam untuk berinternet [Indonesians spend almost 8 hours on the Internet]. Retrieved from https://databoks.katadata.co.id/datapublish/2020/02/26/indonesia-habiskan-hampir8-jam-untuk-berinternet

Gezgin, D. M., Cakir, O., \& Yildirim, S. (2018). The relationship between levels of nomophobia prevalence and Internet addiction among high school students: The factors influencing nomophobia. International Journal of Research in Education and Science, 4(1), 215-225. doi:10.21890/ijres.383153

Hakim, S. N., \& Raj, A. A. (2017). Dampak kecanduan Internet (Internet addiction) pada remaja [Impacts of Internet addiction on adolescents]. In Prosiding Teтu Ilmiah Nasional X Ikatan Psikologi Perkembangan Indonesia. 20-24. Semarang: Unissula.

Hasanzadeh, R., Beydokhti, A., \& Zadeh, F. D. (2012). The prevalence of Internet addiction among university students: A general or specific problem. Journal of Basic and Applied Scientific Research, 2(5), 5264-5271.

Holt, N. A., \& Kleiber, D. A. (2009). The sirens' song of multiplayer online games. Children Youth and Environments, 19(1), 223-244.

Hsu, S. H., Wen, M. H., \& Wu, M. C. (2009). Exploring user experiences as predictors of MMORPG addiction. Computers \& Education, 53(3), 990-999. doi:10.1016/j.compedu.2009.05.016

King, D. L., Gradisar, M., Drummond, A., Lovato, N., Wessel, J., Micic, G., .... \& Delfabbro, P. (2013). The impact of prolonged violent video-gaming on adolescent sleep: An experimental study. Journal of Sleep Research, 22(2), 137-143. doi:10.1111/j.1365-2869.2012.01060.x

Kim, Y. (2013). Young children in the digital age. Las Vegas: University of Nevada.

Ko, C. H., Yen, J. Y., Chen, C. S., Yeh, Y. C., \& Yen, C. F. (2009). Predictive values of psychiatric symptoms for Internet addiction in adolescents: A 2-year prospective study. Archives of Pediatrics \& Adolescent Medicine, 163(10), 937-943. doi:10.1001/archpediatrics.2009.159

Kusumawardani, S. P. (2015). Game online sebagai pola perilaku (studi deskriptif tentang interaksi sosial gamers clash of clans pada clan indo spirit) [Online games as behavioral patterns (a descriptive study of the social interaction of gamers in clash of clans in indo spirit clans)]. Jurnal Antropologi FISIP Universitas Airlangga, 4(2), 154-163.

Leung, L., \& Lee, P. S. (2016). Impact of Internet literacy, Internet addiction symptom and Internet activities on academic performance. Social Science Coputer Review, 30(4), 403-418. doi:10.1177/0894439311435217

Li, W., O’Brien, J. E., Snyder, S. M., \& Howard, M. O. (2015). Characteristics of Internet addiction/pathological Internet use in US university students: A qualitative method investigation. PloS ONE, 10(2), e0117372. doi: 10.1371/journal.pone.0117372 
Masya, H., \& Candra, D. A. (2016). Faktor-faktor yang mempengaruhi perilaku gangguan kecanduan game online pada peserta didik kelas X di Madrasah Aliyah Al Furqon Prabumulih tahun pelajaran 2015/2016 [Factors that influence online game addiction disorder behavior in class X students at Madrasah Aliyah Al Furqon Prabumulih in the academic year 2015/2016]. KONSELI: Jurnal Bimbingan dan Konseling, 3(2), 97-112.

Montag, C., \& Reuter, M. (2017). Molecular genetics, personality and internet addiction revisited. In Montag, C., \& Reuter, M. (Eds). Internet addiction (pp. 141-160). Switzerland: Springer International Publishing.

Mudrikah, C. (2019) Hubungan antara sindrom FOMO (fear of missing out) dengan kecenderungan nomophobia pada remaja [The relationship between the FOMO syndrome (fear of missing out) and the tendency of nomophobia in adolescents] (Undergraduate thesis). UIN Sunan Ampel Surabaya.

Mustafa, K. O. Ç. (2011). Internet addiction and psychopatology. TOJET: The Turkish Online Journal of Educational Technology, 10(1), 143-148

Perdew, L. (2014). Internet addiction. Minneapolis: Abdo Publishing.

Tauba, A., Suryani, S., \& Rafiyah, I. (2020). The lived experiences of the Lombok earthquake survivors. Nurse Media Journal of Nursing, 10(1), 22-35. doi:10.14710/nmjn.v10i1.24964

Wee, C. Y., Zhao, Z., Yap, P. T., Wu, G., Shi, F., Price, T., ..., \& Shen, D. (2014). Disrupted brain functional network in Internet addiction disorder: A resting-state functional magnetic resonance imaging study. PLoS ONE, 9(9), e107306. doi:10.1371/journal.pone.0107306

Weinstein, A., Dorani, D., Elhadif, R., Bukovza, Y., Yarmulnik, A., \& Dannon, P. (2015). Internet addiction is associated with social anxiety in young adults. Annals of Clinical Psychiatry, 27(1), 4-9. doi:10.1093/med/9780199380183.003.0001

Wijaya, P.G.P.M, Wijayanthi, I.A.S, \& Widyastuti, K. 2019. Hubungan posisi dan lama duduk dengan nyeri punggung bawah pada pemain game online [The relationship between position and length of sitting with lower back pain in online game players]. Intisari Sains Medis, 10(3), 834-839. doi:10.15562/ism.v10i3.495

Ybarra, M. L., Alexander, C., \& Mitchell, K. J. (2005). Depressive symptomatology, youth Internet use, and online interactions: A national survey. Journal of Adolescent Health, 36(1), 9-18. doi:10.1016/j.jadohealth.2003.10.012

Yen, C. F., Chou, W. J., Liu, T. L., Yang, P., \& Hu, H. F. (2014). The association of Internet addiction symptoms with anxiety, depression and self-esteem among adolescents with attention-deficit/hyperactivity disorder. Comprehensive Psychiatry, 55(7), 1601-1608. doi:10.1016/j.comppsych.2014.05.025

Yang, S. C., \& Tung, C.-J. (2007). Comparison of Internet addicts and non-addicts in Taiwanese high school. Computers in Human Behavior, 23(1), 79-96.

Young, K. S., \& De Abreu, C. N. (2011). Internet addiction. A handbook and guide to evaluation. New Jersey, PA: John Wiley \& Sons, Inc.

Young, K. (2017). Internet addiction: Neuroscientific approaches and therapeutical implications including smartphone addiction. Switzerland: Springer International Publishing

Young, K. (2009). Internet addiction: A new clinical phenomenon and its consequences. American Behavior Scientist, 48, 402-415. 